In: Naamkunde 32 (2000), Afl. 1-2, p. 7 - 35.

\title{
Cartografie in de naamkunde
}

\section{Inleiding}

Toen ik bij de voorbereiding van deze bijdrage deel 2 van de topografische atlas van Nederland, het deel over Noord-Nederland, opsloeg, en wat gemeentenamen bekeek in wat voor mij het verst gelegen deel van het Nederlandse taalgebied is, stootte ik op een groot aantal namen die mij helemaal niet vertrouwd in de oren klinken : b.v. Harkema, Doezum, Kollumerzwaag, Garrelsweer, Appingedam, Scharmer, Harkstede, Loppersum, Wolvega, Woltersum, Rotsterhaule, Nieuw-Beerta enz. Een Nederlander die Vlaanderen doorkruist, heeft waarschijnlijk dezelfde ervaring als hij voorbij plaatsnaamborden met b.v. Kuttekoven, Kruishoutem, Erwetegem, Godveerdegem, Bachte-Maria-Leerne, Sinaai, Dikkebus, Winkelom-Heide, Kwaremont, Lieferinge enz. erop rijdt.

$\mathrm{Nu}$ is, vooral sinds de dissertatie van $\mathrm{R}$. Rentenaar over vernoemingsnamen, wel bekend dat plaatsnamen spreekwoordelijk beschouwd pootjes kunnen krijgen - voor namen is immigratie vooralsnog geen probleem - maar in de regel kan men ervan uitgaan dat plaatsen en hun namen ter plekke blijven, bij de mensen die die namen ter plaatse gegeven hebben.

Ik heb opzettelijk vrij extreme voorbeelden van plaatsnamen gekozen die hetzij mij, hetzij Nederlanders niet vertrouwd zijn, om duidelijk te maken dat vele plaatsnamen een regionaal karakter hebben. Deze vaststelling geldt ook voor de andere groepen eigennamen : vele familienamen, voornamen, bijnamen en waternamen zijn streekgebonden.

Dat b.v. de verspreiding van familienamen sterk regionaal bepaald is, is al langer bekend. FN als Florizoone, Vandenbussche, De Wulf, Bekaert, Claerhout, Vandecasteele zijn hoofdzakelijk in het westen van Vlaanderen verspreid, waar ze ook zijn ontstaan. Familienamen als Den Uyl, Baars, Tromp, Roest, Koot, Borst, Konijn, Pols, Plomp 
enz. horen nog steeds thuis in het westen van Nederland, in Holland, alle migratoire bewegingen in onze mondiale samenleving ten spijt.

Een familienaam kan men niet kiezen, noch vrijelijk veranderen. Sinds ruim 200 jaar geleden de vererfbaarheid van de Nederlandse familienamen in de Napoleontische wetgeving werd vastgelegd, kan men een familienaam enkel om bijzondere redenen wijzigen. Maar zelfs bij een naamcategorie als de voornaam, waarvan de keuze voor de ouders haast volledig vrij is, verloopt de naamkeuze volgens een landenspecifiek patroon.

Dat blijkt wanneer men de populairste meisjes- en jongensvoornamen in 1997 in Nederland en in het Vlaamse gewest naast elkaar legt : van de tien in 1997 het frequentst gegeven meisjesnamen in $\mathrm{Ne}-$ derland zijn er maar twee die in de vergelijkbare Vlaamse toptien staan: Laura en Lisa. Nederlandse driejarige meisjes heten daarnaast vooral Sanne, Anouk, Anne, Iris, Romy, Demi, Kim en Julia; Vlaamse meisjes heten tegenwoordig vooral Charlotte, Sarah, Jolien, Marie, Julie, Eline en Jana. Wat de jongensnamen betreft, staat de naam Thomas zowel in Vlaanderen als in Nederland op de eerste plaats, maar daar houdt de vergelijking op : Nederlandse jongetjes van een jaar of drie heten bij voorkeur Tim, Kevin, Daan, Nick, Niels, Rick, Max, Tom en Lars; hun Vlaamse kameraadjes heten veeleer Robin, Jonas, Jens, Jordy, Maarten, Stijn, Michiel, Simon, Arne. (1)

De intuïties die men heeft over de regionale specificiteit van de Nederlandse eigennamen kunnen wetenschappelijk gefundeerd worden: dat gebeurt in de tak van de naamkunde die naamgeografie heet.

In deze bijdrage wil ik - overigens zonder daarbij exhaustief te kunnen zijn - aan de hand van verschillende types naamkaarten illustreren welke cartografische methodes in naamgeografische studies gebruikt zijn. Terzelfdertijd ontstaat zo een overzicht van de onomastische disciplines waarin er een naamgeografie tot stand is gekomen of er aanzetten toe ontwikkeld zijn.

(1) De Nederlandse gegevens zijn ontleend aan de website van het Meertens Instituut in februari 2000; de gegevens voor België zijn afkomstig van het Nationaal Instituut voor de Statistiek. 


\section{Cartografische methodes in naamgeografische studies}

\subsection{Toponymie}

In de microtoponymie is het al lang gebruikelijk om de geattesteerde namen in te tekenen op een kaart van de gemeente. De bedoeling van dergelijke topografische kaarten, waarop iedere perceelsnaam wordt ingetekend, is deze toponiemen lokaal te identificeren, als hulpmiddel voor de etymologische naamverklaring.

Wanneer de lokalisering van toponiemen in het onderzoek op de voorgrond staat, kunnen lokale namenatlassen tot stand komen. Een voorbeeld van een dergelijke veldnamenatlas is te vinden even over de grens, in Westfalen, waar de inventarisatie en publicatie van de veldnamen van de 17 gemeenten van het district Borken in de vorm van namenatlassen en -registers goed vordert. Kaart 1 is ontleend aan deel 5 van de reeks "Westmünsterländische Flurnamen" : die Flurnamen der Stadt Isselburg (CIURAJ e.a. 1990, kaart p. 5). Op deze kaart is de plaatselijke perceelsstructuur gedetailleerd getekend en zijn de veldnamen, opgetekend uit de volksmond, voluit in fonetisch schrift weergegeven.

Van naamgeografie kan echter pas sprake zijn als verschillen en overeenkomsten tussen naamelementen in een groter gebied gekarteerd en geïnterpreteerd worden.

In Vlaanderen heeft Jan Lindemans op dit gebied pionierswerk verricht. Met zijn studies over achtereenvolgens de -heem-namen, de -inge-formaties en de kouter-namen (1940), over de namen van het bouwland en het grasland (1946) en over de zele- en de -hove-namen (1954) heeft hij een begin gemaakt met de geografie van toponymische bestanddelen. Hij heeft twee types kaarten getekend: puntsymboolkaarten waarop de verspreiding van één toponymisch bestanddeel wordt afgebeeld (b.v. de verspreiding van de akker-namen in België en Noord-Frankrijk) en vlakkenkaarten waarop het verspreidingsgebied van diverse elementen afgebakend wordt. Kaart 2 uit Lindemans 1946, met de verspreiding van de toponymische heteroniemen beemd/meers/ meet-made in België en Noord-Frankrijk, is een voorbeeld van een woordgeografische vlakkenkaart. 


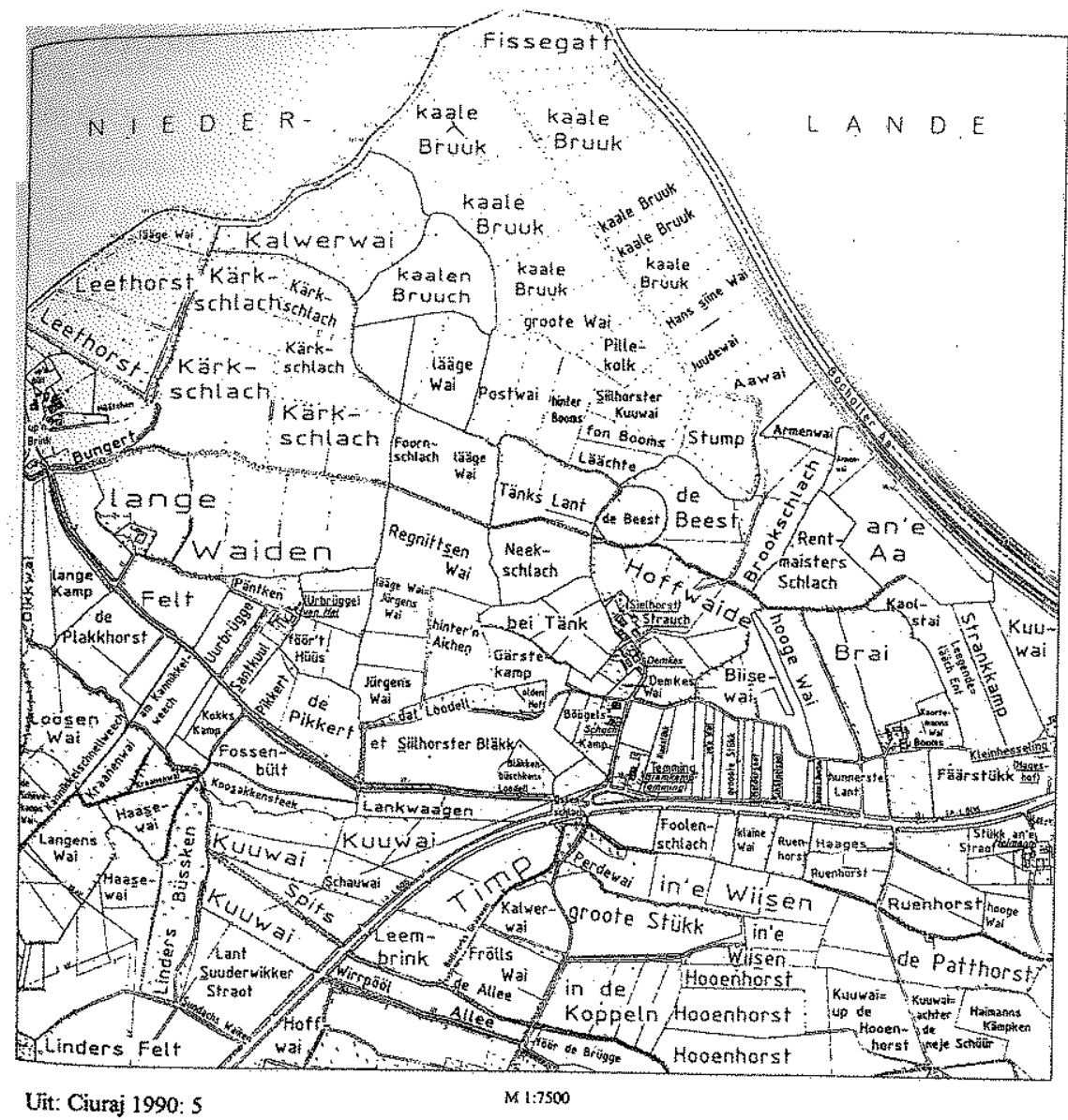

Een voorbeeld van een toponymische puntsymboolkaart waarop ook Nederland behandeld is, is de volgende kaart uit de "Algemene Geschiedenis der Nederlanden (deel I)". Op kaart 3 worden de plaatsnamen uit de Romeinse tijd, de namen die op grond van de etymologie prehistorisch zijn en de plaatsen die genoemd zijn naar wateren met prehistorische namen, voorgesteld door middel van drie verschillende symbolen. De symboolkeuze is op zich arbitrair.

Ook in Bachs Deutsche Namenkunde (BACH 1952-1954) zijn een aantal puntsymboolkaarten te vinden met de verspreiding van toponymische elementen in West-Europa, waarop ook het Nederlandse taalgebied mee opgenomen is. 


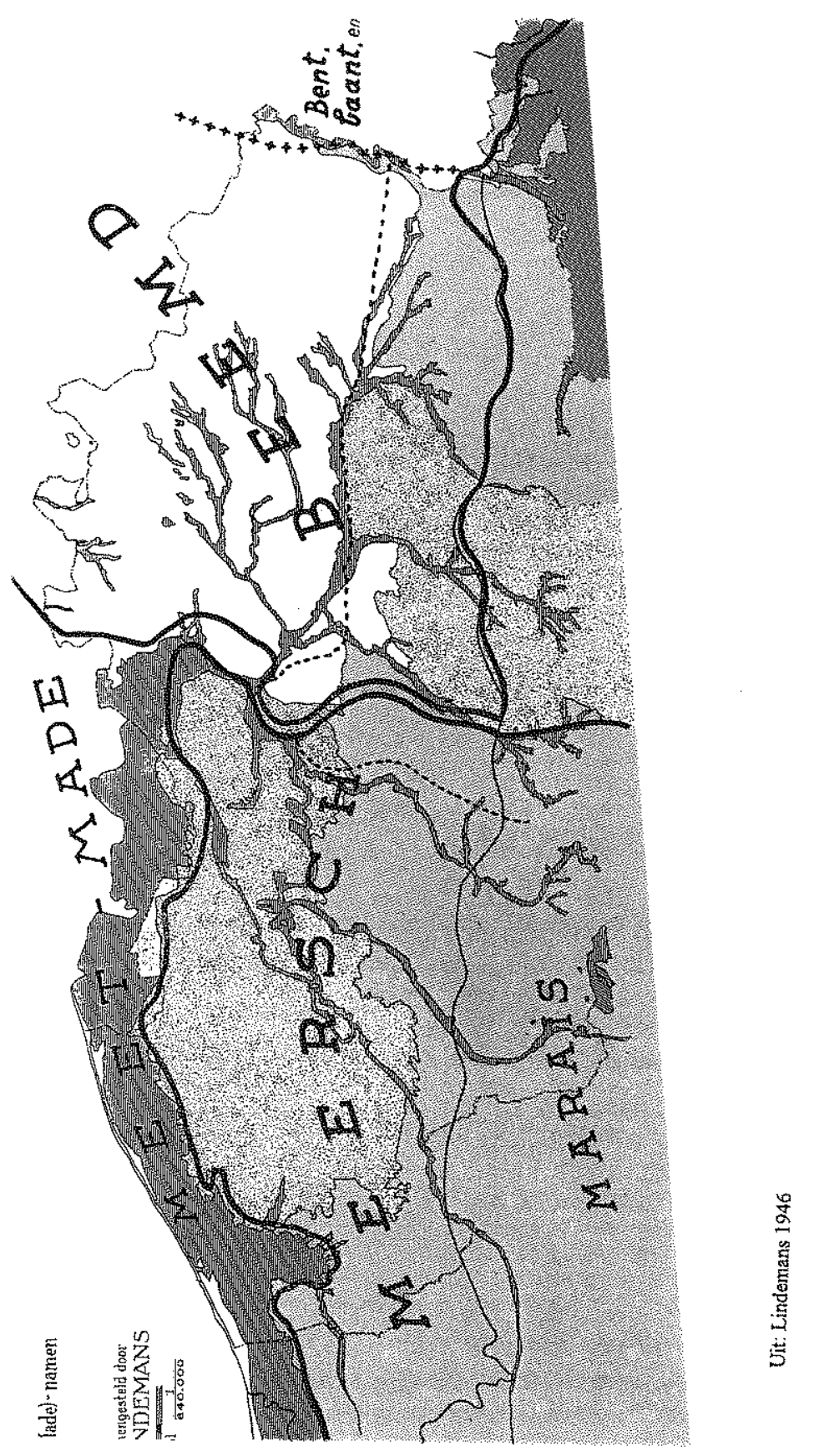


Met de geografie van toponymische elementen in het Nederlandse taalgebied is dus een begin gemaakt, maar een volledige microtoponymische atlas van veldnamen is nog niet tot stand gekomen. Het Leuvense Corpus Molemans-Thiry zou daar voor Vlaanderen het basismateriaal voor kunnen leveren en is al meer dan eens met dat doel gebruikt(2).

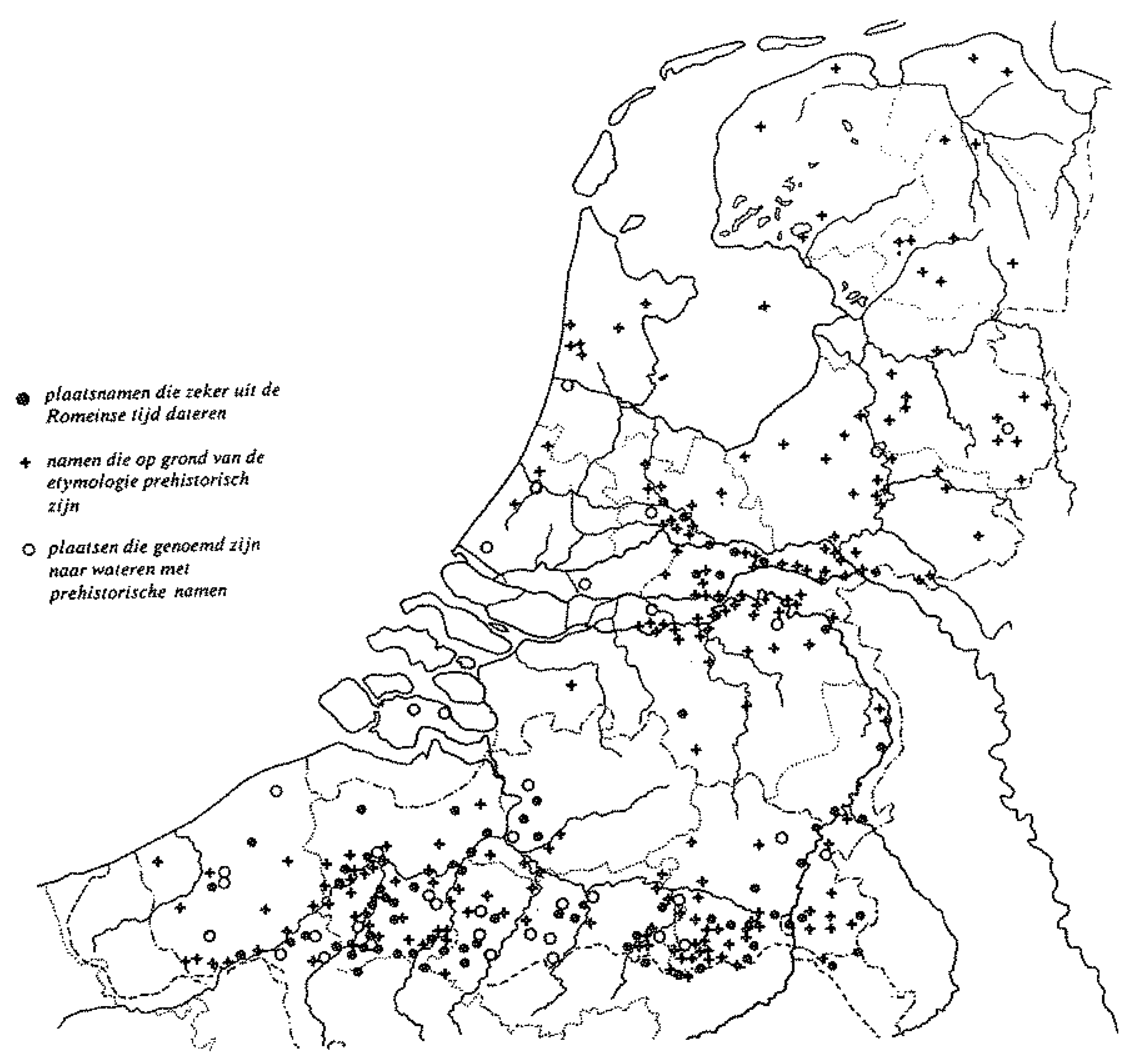

Uit: Algemene Geschiedenis der

Nederlanden dee 1 I

(2) B.v. MARYNISSEN 1990 : over de geografie van de akker-, kouter en rode-namen in Vlaanderen. Ook Devos 1991 ontleent haar toponymische gegevens voor een groot deel aan het Corpus Molemans-Thiry. 
Ik ken wel een zeer geslaagd voorbeeld van een microtoponymische atlas uit het Duitse taalgebied, nl. de Hessischer Flurnamenatlas van

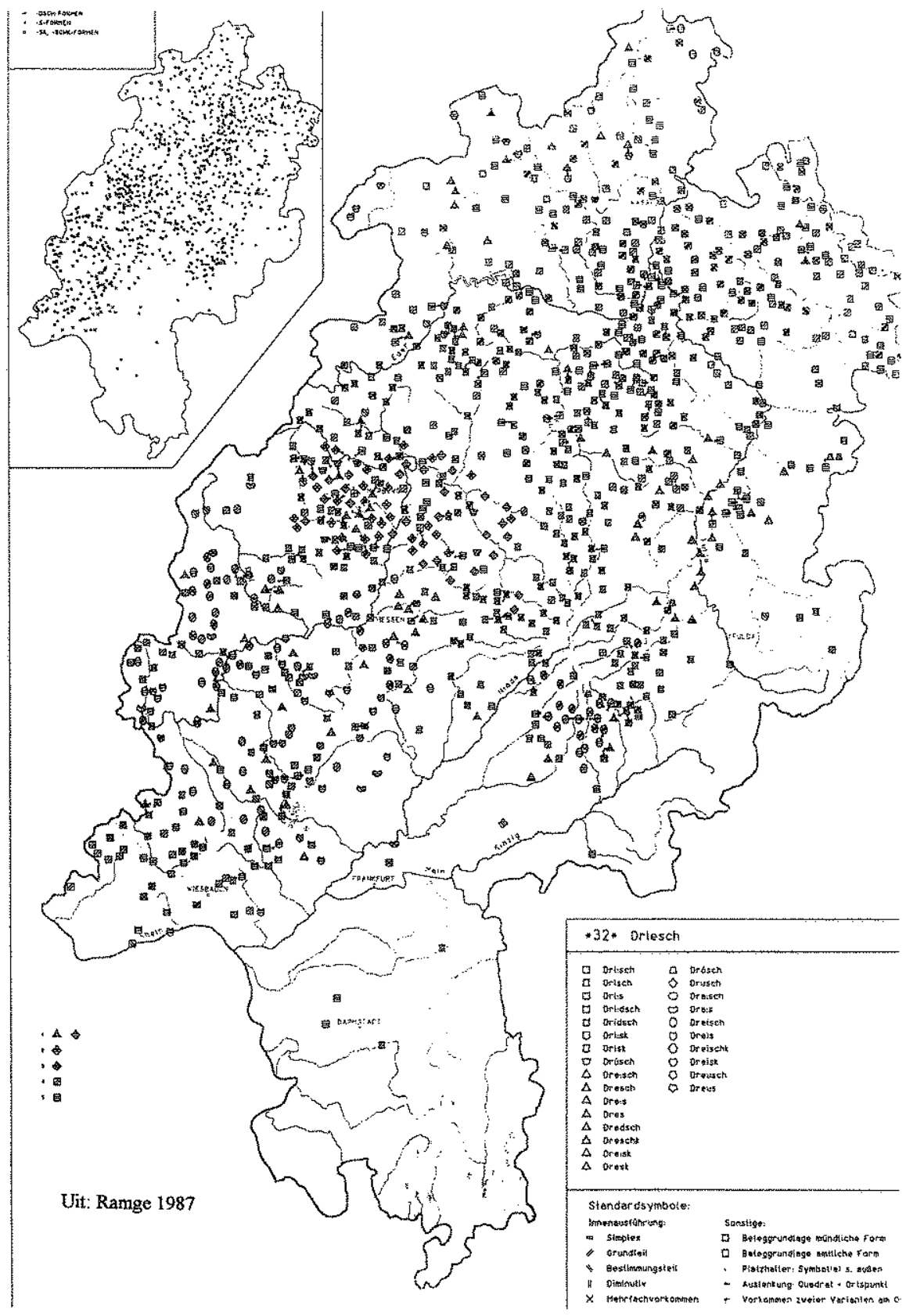


Hans Ramge e.a.(3) (als voorbeeld kaart 4: de varianten van driesch, uit RAMGE 1987). De makers ervan hebben een rigoureus karteersysteem ontworpen waarmee zij zoveel mogelijk grammaticale informatie over de namen konden geven, zonder dat dit een onoverzichtelijk kaartbeeld opleverde. Ze hebben geopteerd voor puntkaarten met complexe symbolen. De fonetische realisatie van de varianten wordt met geometrische figuren voorgesteld; de morfologische informatie zit vervat in verticale strepen (diminutief), horizontale strepen (simplicia) en schuine dubbele strepen (hoofd- of bepalend bestanddeel) waarmee de cirkels, de vierkanten en de veelhoeken worden opgevuld. De aard van de bewijsplaats (mondeling of schriftelijk overgeleverd) wordt typografisch zichtbaar gemaakt door de lijndikte van de omtrek van de symbolen.

Een onontkoombaar probleem bij de vormgeving van dergelijke complexe symboolkaarten is het overlappen van symbolen, telkens als in een plaats meer dan een variant van een type voorkomt. In de Hessense atlas is dit probleem elegant opgelost door de overlappende symbolen uit elkaar te schuiven. De plaats waar de variant feitelijk is opgetekend, wordt aangeduid door middel van een lijntje dat vertrekt op de plaats van attestatie.

Een factor die in deze atlas cartografisch m.i. minder adequaat is voorgesteld, is de frequentie van de varianten. Wanneer een vorm in een plaats meer dan eens voorkomt, volstaat men met een markering voor "Mehrfachvorkommen". De informatie over het aantal dergelijke bewijsplaatsen gaat zo verloren in een standaardsymbool dat niet naar de kwantiteit gedifferentieerd is. Men zou de factor frequentie, zonder een bijkomend symbool te moeten invoeren, kunnen voorstellen door te variëren in symboolgrootte, zodat een betekenisvolle concentratie van een type in een bepaald gebied te zien zou zijn. Nu kan men informatie over de frequentie enkel uit het commentaar bij de kaarten halen.

Van belang voor Vlaanderen is het proefschrift van Magda Devos: "Bouwlandtermen in de Vlaamse dialecten. Spreidings- en betekenis-

(3) Zie ook MARYNISSEN 1992 : review artikel over deze atlas. 
geschiedenis" (1991). In haar dissertatie onderneemt ze een diachroongeografisch woordveldonderzoek van een aantal bouwlandtermen in de Vlaamse dialecten. Daarbij worden gegevens uit de dialecten als vanzelfsprekend met toponymische gegevens gecombineerd.
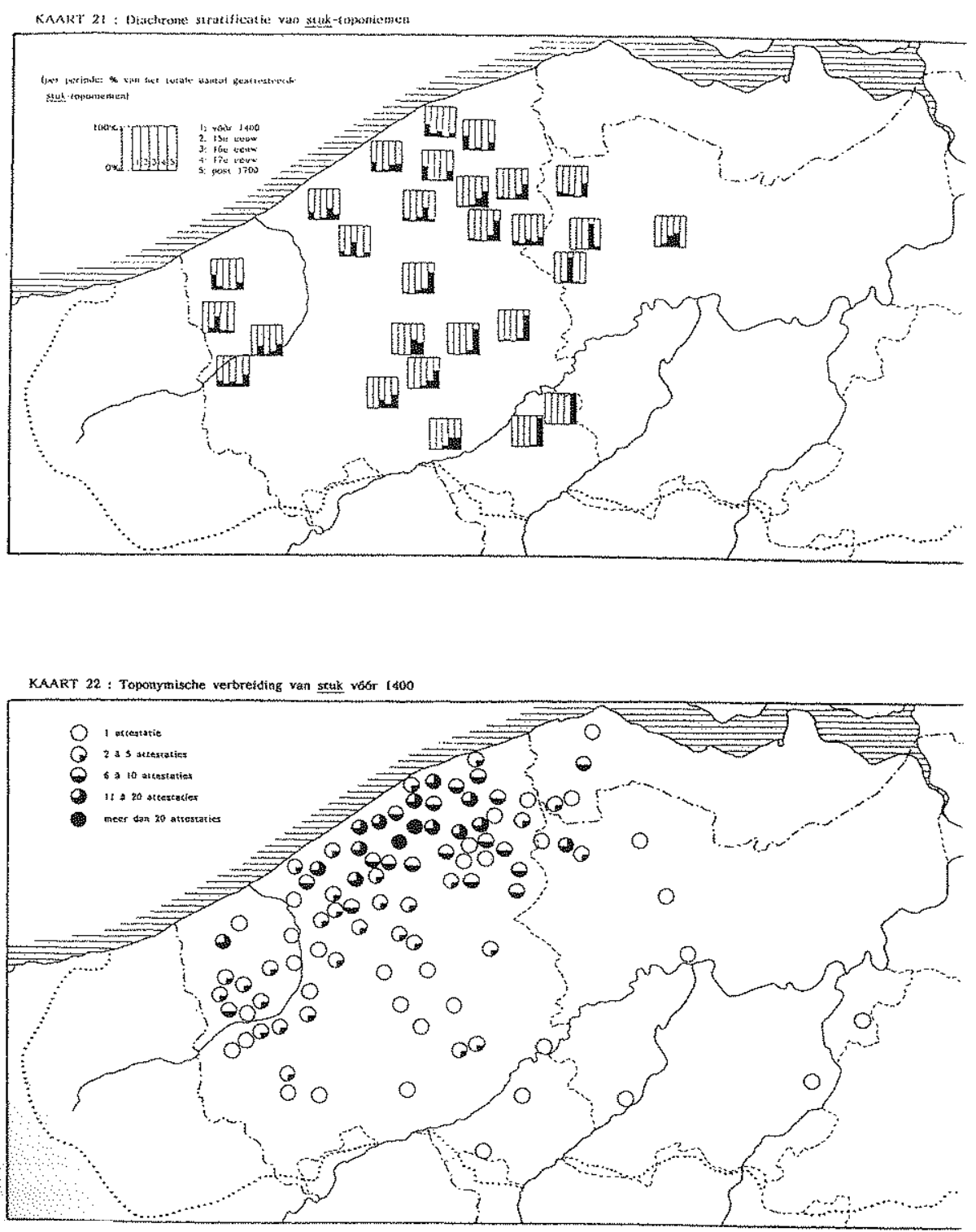

Uit: Devos 1991 
Cartografisch interessant in deze studie is de weergave van de diachrone stratificatie van toponymische elementen, b.v. van het toponiem stuk (kaart 5 : kaarten 21-22 uit DEVOS 1991). In het gebruikte complexe symbool op kaart 21 , een in vijf vakjes verdeeld vierkant, wordt de factor tijd weergegeven in horizontale richting en de factor frequentie in verticale richting. Uit de inkleuring van de vakjes wordt de toeof afname van stuk-toponiemen, procentueel uitgedrukt ten opzichte van het totale aantal geattesteerde stuk-toponiemen, over een periode van minimaal vijf eeuwen zichtbaar. Deze methode is bekend uit de historische taalgeografie (voor een overzicht, zie GOOSSENS 1995a), maar wordt hier bij mijn weten voor het eerst toegepast op de Nederlandse toponymie. De aanvullende kaart 22, de toponymische verbreiding van stuk vóór 1400, laat de frequentie van stuk-toponiemen in absolute aantallen zien. De mate waarin het taartdiagram opgevuld is, correspondeert met de absolute aantallen stuk-attestaties. Op deze manier wordt de geografische concentratie van stuk-toponiemen vóór 1400 visueel duidelijk. Het relatieve aantal toponiemen met stuk in de lokale toponiemenbestanden wordt op kaart 20 voorgesteld met behulp van geheel of gedeeltelijk zwart gemaakte staafdiagrammen (kaart 6 : kaart 20 uit DEVos 1991).

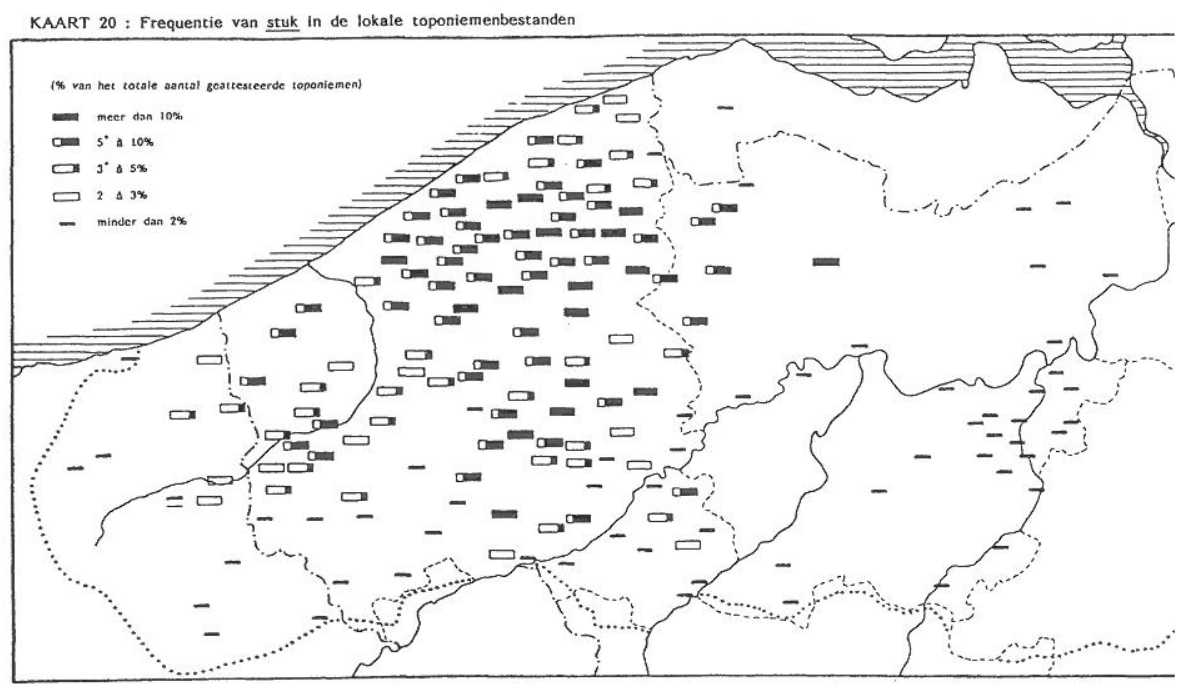

Uit: Devos 1991 
Soortgelijke frequentiekaarten op basis van toponymisch materiaal zijn gemaakt door Günter Müller bij zijn voorbereidingen voor een "Westfälisch-Lippischer Flurnamenatlas" (MÜLLER 1984). In dit artikel experimenteert hij volop met types taalkaarten die op basis van het materiaal uit het Westfälisches Flurnamenarchiv getekend kunnen worden.

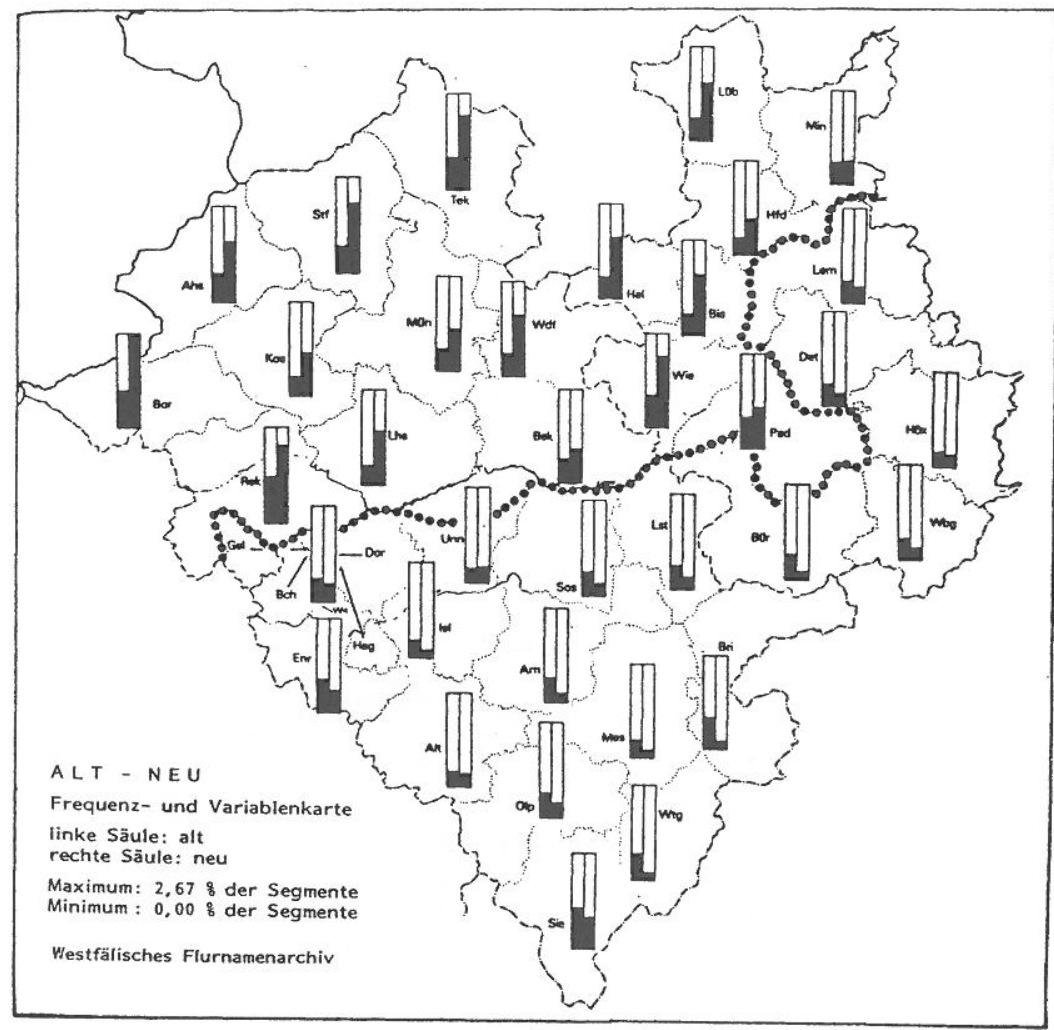

Uit: Müller 1984

Karte 19

Karte 19 uit Müller 1984 (kaart 7) is een combinatie van een frequentie- en een variabelenkaart. Ze stelt de relatieve frequentie voor van toponiemen die met alt en met neu gevormd zijn : de linkerzuil geeft de relatieve frequentie van de variabele alt weer, de rechterzuil de relatieve frequentie van het antoniem neu. Deze kaart toont een geografische tweedeling: in het noordelijke deel van Westfalen-Lippen domineert neu in toponymische samenstellingen en woordgroepen; in het zuide- 
lijke deel is er een overwicht aan alt-vormen. Müller markeert deze ruimtelijke dichotomie met een bolletjeslijn op de kaart, waardoor deze de facto een combinatie van een puntkaart met complexe symbolen en een vlakkenkaart wordt.

De romanist Alf Monjour heeft enkele jaren geleden de methode die in de atlas van Dées $(1980,1987)$ gebruikt is, toegepast op de Franse toponymie. Deze methode gaat in feite terug op de manier waarop Heeroma in de familienaamgeografie zgn. kernnamen gekarteerd heeft (cfr. GoOSSENS 1995a:188). Monjour heeft de geografische verspreiding van plaatsnamen op $-n y(<n+$ Galloromeins suffix -iacu) op vlakkenkaarten voorgesteld (kaart 8 : Carte 1 uit Monjour 1993). De vlakken staan voor de Franse departementen en de Waalse provincies. De frequentie van de plaatsnamen op - ny (tussen 0 en meer dan 5 voorkomens per departement of provincie) komt tot uiting in de wijze van arcering : zwart, geruit of gestreept.

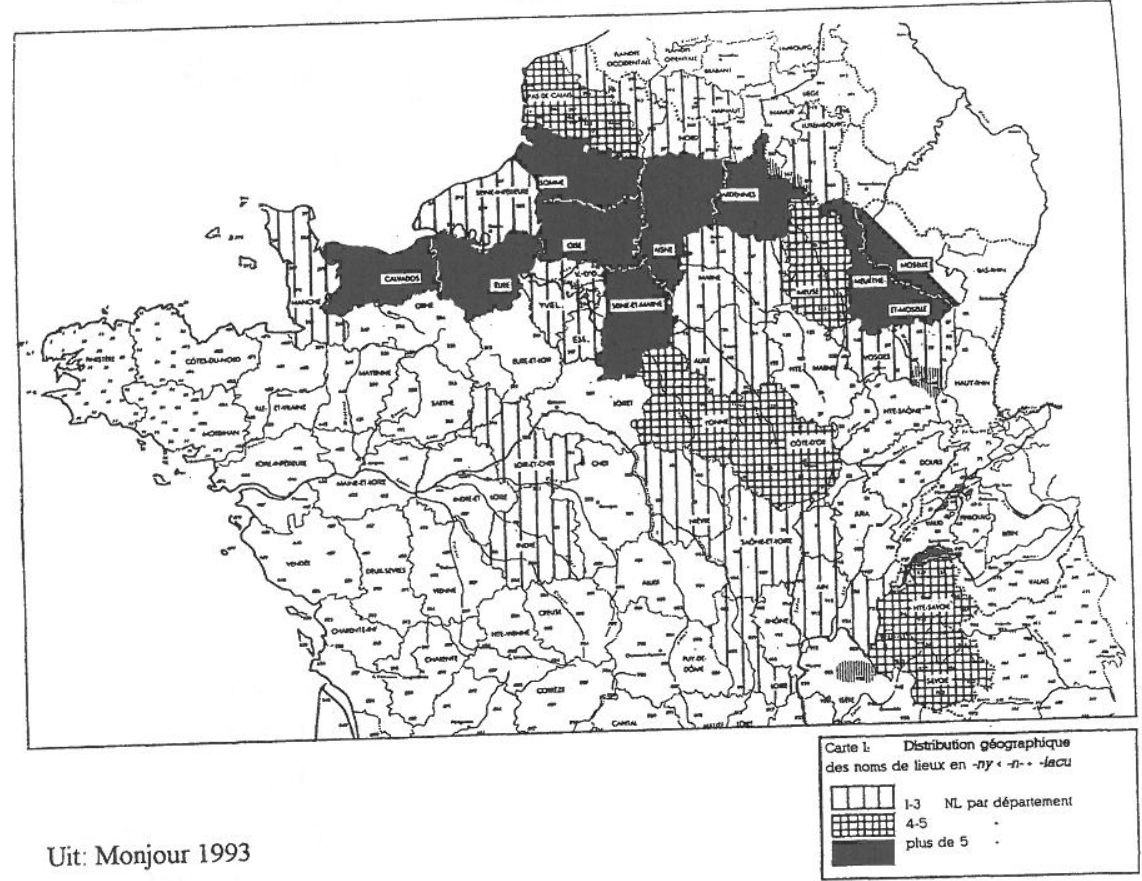

Ik begrijp Monjours werkwijze in het licht van zijn probleemstelling : hij wilde aan de hand van de verspreiding van plaatsnamen nagaan of 
men dialectale ruimtes ("des espaces dialectaux") kan onderscheiden. Maar naamgeografisch beschouwd, zou hij m.i. een preciezer resultaat verkregen hebben als hij de ligging van iedere plaatsnaam op -ny eenvoudig met een symbool op de kaart had getekend, eventueel met een in grootte variërend symbool ter aanduiding van de frequentie, indien hij per departement maar één symbool had willen intekenen. Met de huidige karteerwijze wordt overigens niet duidelijk hoeveel attestaties "meer dan 5 voorkomens per departement" dan wel zijn, hoewel uit de tekst van het artikel blijkt dat hij niet over een overweldigende hoeveelheid materiaal beschikte.

\subsection{Hydronymie}

Ook met de geografie van waternamen is een begin gemaakt: in het noorden door K. Gildemacher, in zijn proefschrift "Waternamen in Friesland" (1993); in het zuiden door P. Kempeneers, in zijn dissertatie over de hydronymie van het Dijle- en Netebekken (1982). Beide studies bevatten een aantal klassieke puntsymboolkaarten waarop de lokale verspreiding van hydronymische elementen is getekend. Karteertechnisch gezien bevatten deze studies geen nieuwigheden; ik ga er dan ook niet verder op in.

\subsection{Antroponymie}

De geografische studie van persoonsnamen is in het Nederlandse taalgebied vooral goed ontwikkeld op het gebied van de familienamen.

Dat betekent niet dat er niets gedaan is op het gebied van de verspreiding van bijnamen en voornamen.

Een eerste, oriënterend onderzoek naar de geografie van bijnamen is de studie van Van Langendonck uit 1991: "Geografie van de voor- en toenaampatronen in de Vlaamse dialekten".

Een geografie van voornamen bestaat voor het Nederlands niet, maar is voor het Duitse taalgebied op een gevarieerde manier uitgewerkt door Konrad Kunze 19992 in diens "DTV-Atlas Namenkunde, Vor- und Familiennamen im deutschen Sprachgebiet". 
De Nederlandse familienamen vormen al lang een rijke bron van onderzoek, die dan ook door heel wat naamkundigen is aangeboord. Afhankelijk van de vraagstelling en van het materiaal waarover men beschikte, zijn er in de Nederlandse familienamengeografie verschillende karteerwijzen gebruikt. Ik beperk mij hier tot een overzicht van de gebruikte karteertechnieken. Een synthese van de linguïstische verworvenheden van de familienamengeografie is te vinden in Goossens 1996.

In de FN-geografie worden in wezen dezelfde methodes gebruikt als in de toponymie : de vlakkenmethode enerzijds en de puntmethode anderzijds.

De vlakkenmethode is vaak gebruikt in studies die gemaakt zijn toen de eerste delen van het Nederlands Repertorium van Familienamen begonnen te verschijnen. Vooral Heeroma heeft deze methode veelvuldig gebruikt, maar ook Buitenhuis en Miedema hebben vlakkenkaarten getekend.

Heeroma heeft in eerste instantie de verspreiding van afzonderlijke namen onderzocht, b.v. de FN De Vries, De Jong, Drenth, De Jonge. Hij tekent vlakkenkaarten met arceringen die de relatieve frequentie van de namen aangeven : hij berekent het aantal naamdragers ten opzichte van het totale aantal inwoners in iedere gemeente en drukt dat in procenten uit, b.v. kaart 9 : kaart De Vries uit Heeroma 1965.

Zelf maak ik eveneens verspreidingskaarten van één naam, maar in de legende vermeld ik de absolute aantallen. Voor deze met de computer getekende kaarten maak ik voor Nederland gebruik van het PTTbestand met de FN van alle Nederlandse telefoonabonnees in 1993, waarvan tenminste twee naamdragers in dezelfde gemeente wonen. Het computerbestand voor België bevat de familienamen van alle inwoners van België op 31-12-1987, waarvan er tenminste vijf in een gemeente wonen. Dit bestand is afkomstig van het Nationaal Instituut voor de Statistiek en is gebaseerd op het Rijksregister. Het computerprogramma dat Paul Bijnens in 1990 voor België gemaakt heeft, in 1993 uitgebreid heeft naar Nederland en daarna herhaaldelijk aangepast heeft, maakt telkens opnieuw, bij iedere selectie van een FN, een aangepaste schaalverdeling in 5 graden, die elk een kleur krijgen in de le- 
gende. Bij een afdruk op papier worden die kleuren verschillende grijswaarden (cfr. MARYNISSEN 1997: 26-29).

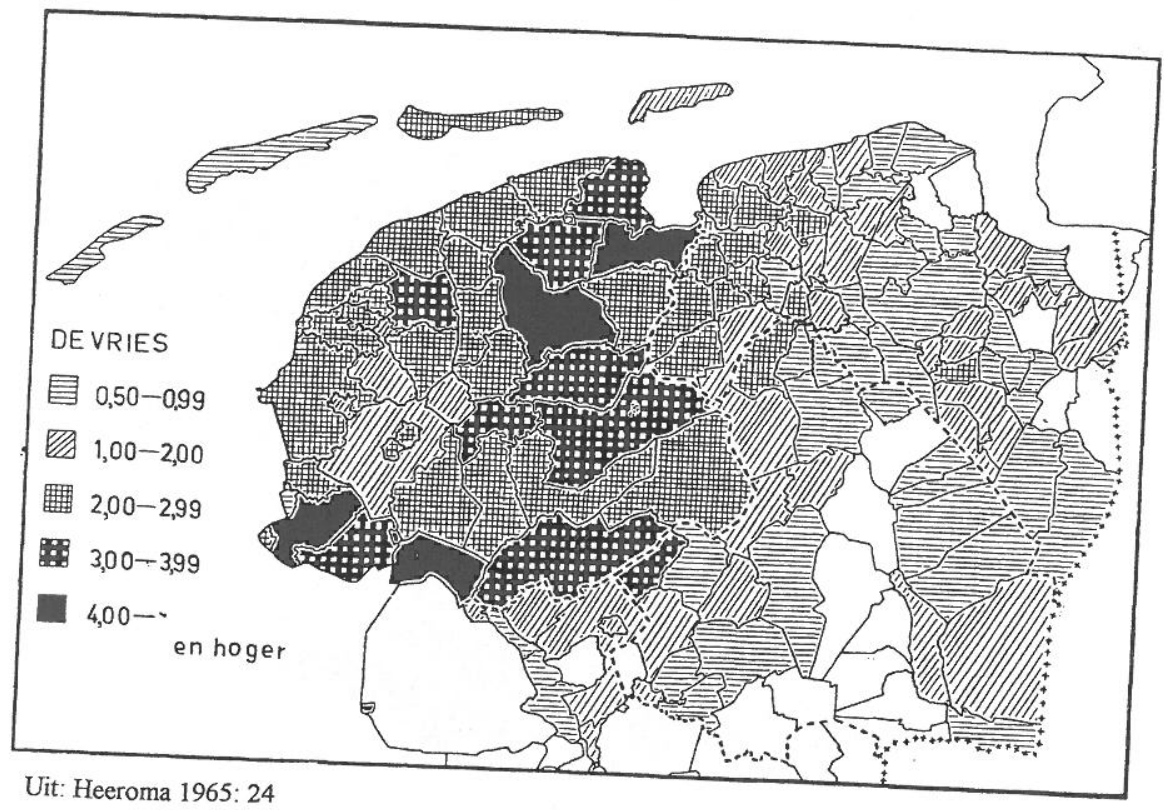

Evenals op Heeroma's kaart is ook op mijn verspreidingskaart van de FN De Vries (kaart 10 : De Vries) die naam het best verspreid in Friesland zelf en neemt de frequentie van de naam af naar het zuiden toe, waar er toch enkele Nederlandse gemeenten zijn die het zonder een $\mathrm{De}$ Vries moeten stellen.

Dat Heeroma's kaarten en mijn kaarten goed overeenstemmen, hoeft niet te verwonderen. Ik heb keer op keer vastgesteld dat familienamen geconcentreerd voorkomen in een bepaalde streek. Haast bij iedere $\mathrm{FN}$ die op het scherm wordt opgeroepen, is er een kerngebied waar de naam zeer frequent is, dat dan uitdijt naar de wijdere omgeving, waar de frequentie van de naam afneemt(4). Verbrokkelde kaart-

(4) Voor deze gelegenheid heb ik de proef op de som genomen met de naam Rentenaar. De bakermat van deze veeleer zeldzame familienaam ligt volgens mijn vestigd. 
beelden, met opvallende lacunes op de kaart, zijn zeldzaam en wijzen vaak op het uitsterven van de naam (cfr. MARYNISSEN 1997:30-31).

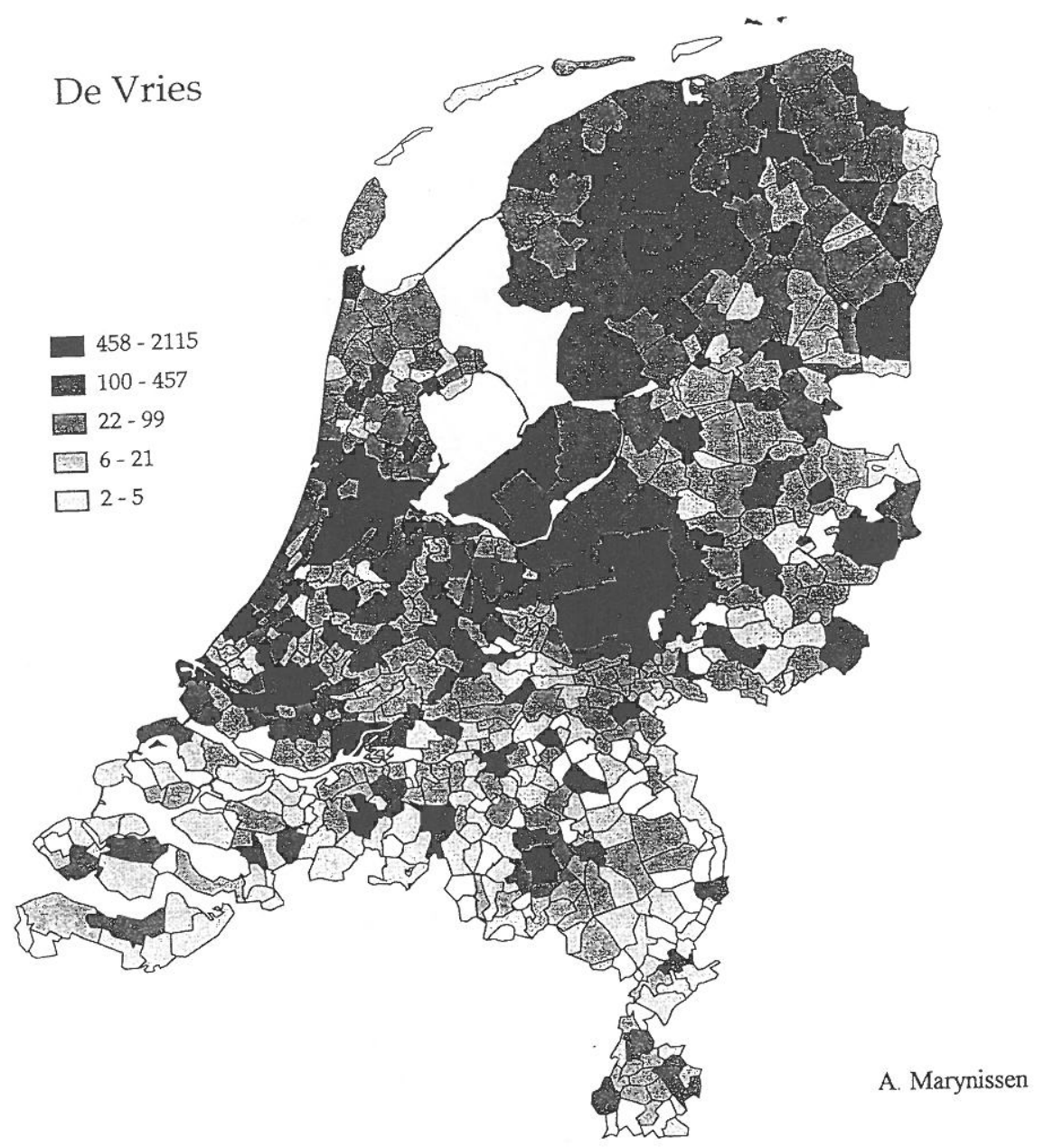

Mijn ervaring met dit type kaarten is dat ze bij het grote publiek bijzonder aanslaan, met de genealogen op kop. Meestal bevestigt de kaart wat men intuïtief al wist : dat zijn familie in deze of gene streek woont. Een linguïstische probleemstelling bevatten deze kaarten echter niet. 
Men kan één familienaam ook karteren met de puntmethode. Dat heeft Buitenhuis in 1977 gedaan met opnieuw de FN De Vries, dit keer voor heel Nederland (kaart 11: BUITENHUIS 1977:46). De frequentie zit vervat in de keuze van verschillende symbolen.

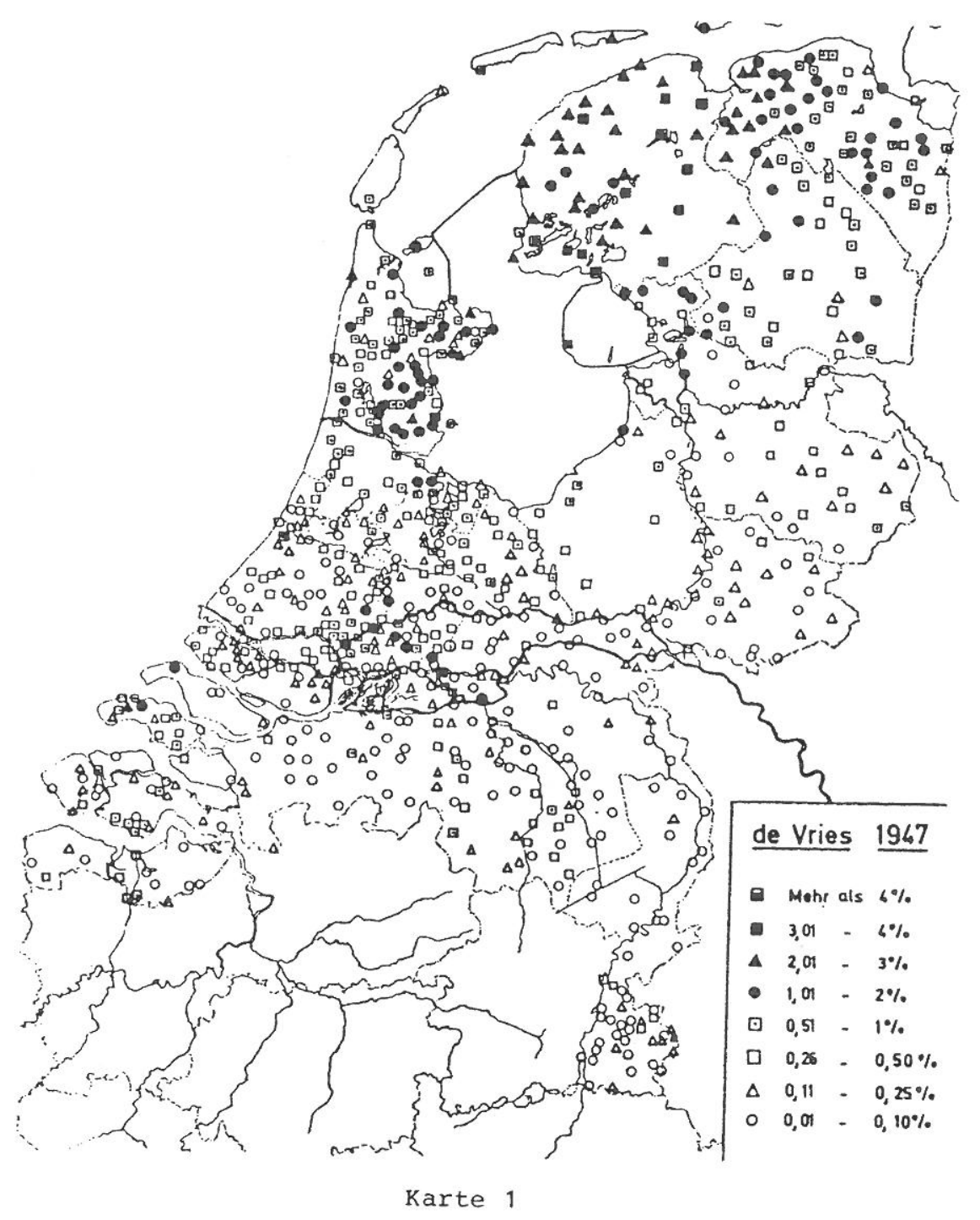

Uit: Buitenhuis 1977: 46 
Als men de puntmethode gebruikt om de verspreiding van één naam te laten zien, krijgt men mijns inziens een duidelijker kaartbeeld wanneer men het bij één symbool houdt, dat men laat variëren in grootte naargelang de frequentie : b.v. de familienaam Van Schaik en varianten (kaart 12 : HEEROMA 1972:33). Met varianten bedoelt Heeroma een orthografische variant van Van Schaik: met $c k$ geschreven in plaats van $k$. Heeroma makt hier dus eigenlijk een groepering van twee naamvormen. Hier werkt hij ook met absolute aantallen in plaats van met relatieve frequenties.

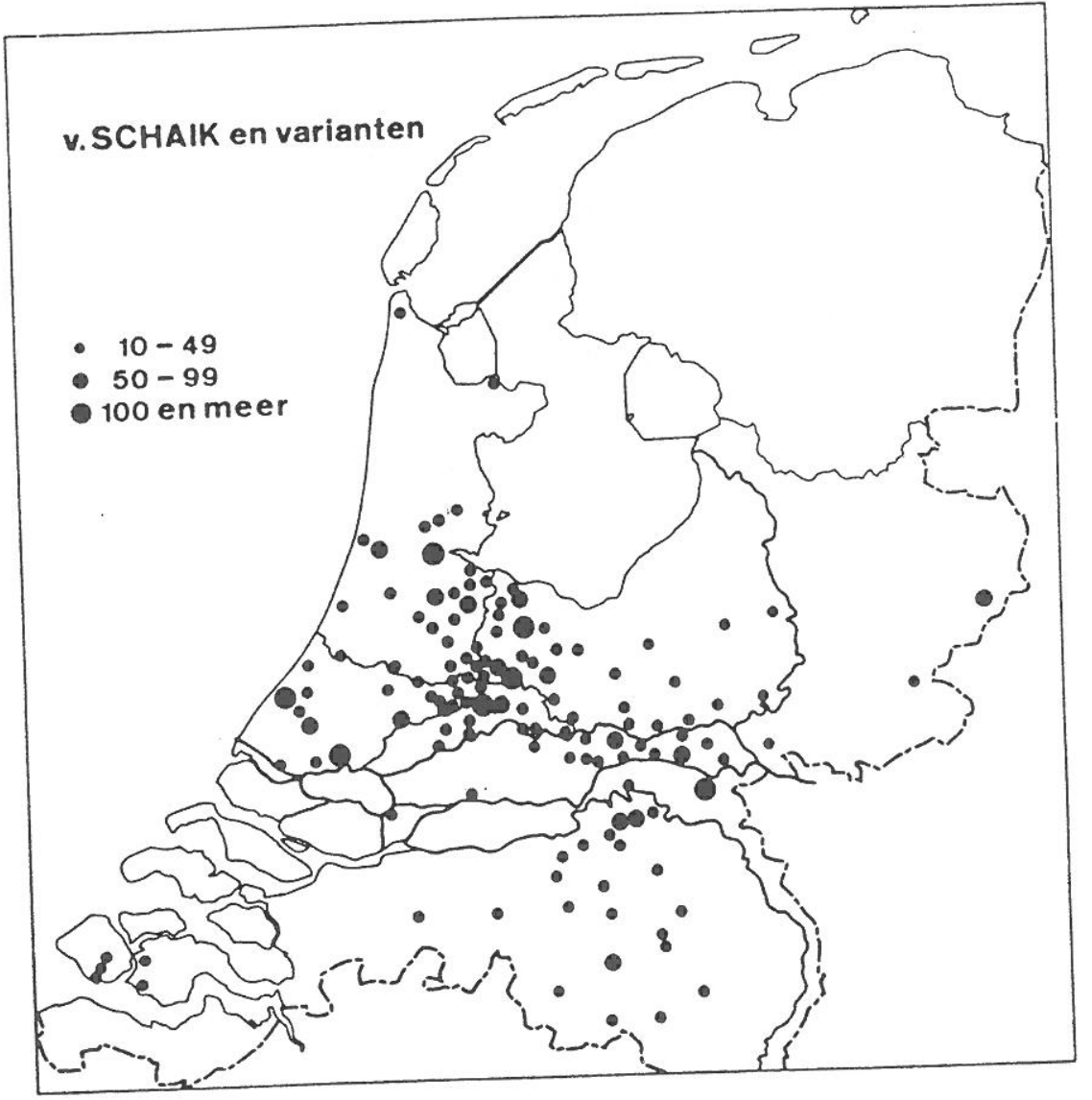

Uit: Heeroma 1972: 33 
Heeroma heeft overigens snel een stap verder gezet dan het louter karteren van afzonderlijke namen. Hij blijft vlakkenkaarten met arceringen die de relatieve frequentie van de namen weergeven, tekenen, maar gaat al snel van een andere probleemstelling uit, meer bepaald van de vraag naar de verspreiding van morfologische naamtypes(5). Voorbeelden zijn zijn kaarten met de geografische verdeling van namen op - $a$ in Friesland, van FN op -ing en -ink en van namen die met te, ter, ten beginnen in het noordoosten van Nederland (voorbeeld: kaart 13: HEEROMA 1968:10 : namen op -ing + -ink).

Om de regionale verdeling van morfosyntactische types familienamen te karteren, hetgeen wel de kernactiviteit van de linguïstische naamgeografie is, lijkt de puntsymboolmethode mij echter een geschiktere methode. Op puntsymboolkaarten kan men voor ieder type een apart teken kiezen. Wanneer men dit symbool kan laten variëren in grootte, biedt deze methode ook het voordeel dat men frequentieverhoudingen van varianten kan laten zien. Menggebieden komen bovendien tot hun recht als men op één plaats verschillende symbolen kan tekenen. Vaak stoten we immers op overgangsgebieden waarin twee of meer contrasterende types naast elkaar voorkomen. De frequentieverhouding tussen de varianten maakt dan duidelijk welk type dominant is of een minderheidspositie inneemt.

Een mooi voorbeeld van een morfologische tegenstelling bij de patroniemen is de geografische verdeling van het genitieftype en het nominatieftype bij de namen met het Germaanse element -brecht als tweede lid. Een voornaam met -brecht kon in het zuiden van het taalgebied op twee manieren tot FN worden : door toevoeging van de genitiefuitgang $-s$ (genitieftype) of zonder toevoeging van een uitgang (nominatieftype). De realisatie van beide mogelijkheden levert namen-

(5) De mogelijkheid om naamtypes te karteren, was al in 1956 geopperd door D.P. Blok: "Hetzelfde geldt, hoewel de eventuele resultaten zich minder duidelijk zullen aftekenen, voor de antroponymie, waar men, uitgaande van volledig materiaal, de frequentie van namentypen in kaart kan brengen."

Citaat uit D.P. BLOK, Resultaten van de geografische methode bij de Nederlandse naamkunde. In : Handelingen van het Vierentwintigste Nederlands Filologencongres gehouden te Amsterdam 5-6 april 1956. Groningen, 1956, p. 103. 
paren op als Aelbrecht/Aelbrechts, Robbrecht/Robbrechts, Lambrecht/ Lambrechts enz.

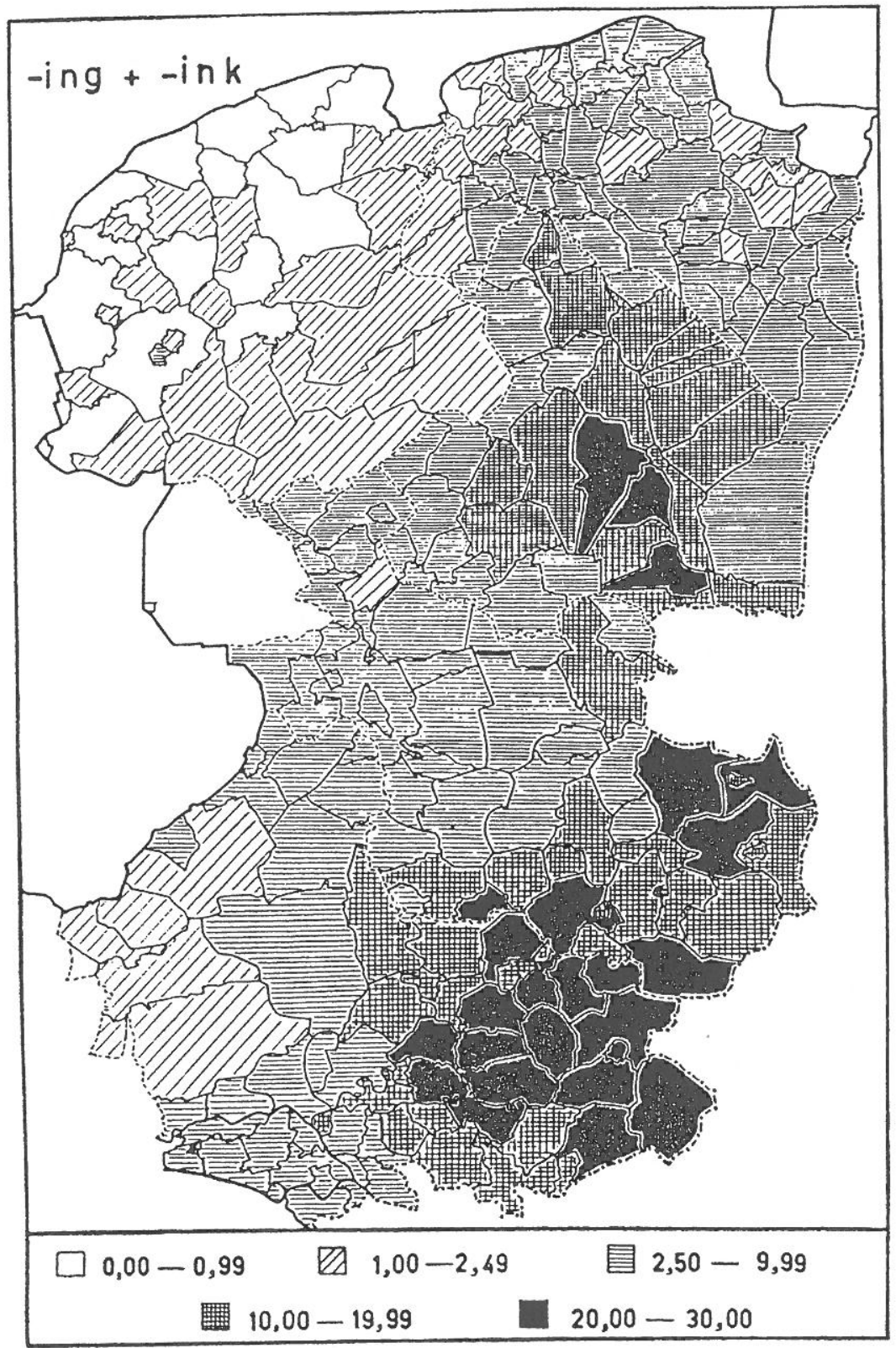

Karte 4

Uit: Heeroma 1968: 10 
Er zijn in totaal meer dan 200 verschillende familienamen met -brecht. Het Belgische FN-bestand bevat 93 schrijfvarianten van 16 verschillende samenstellingen met -brecht(s) Het Nederlandse bestand telt 103 schrijfvarianten van 21 verschillende patroniemen met -brecht(s). Op kaart 14 heb ik de genitiefvormen gezamenlijk afgezet tegenover de nominatiefvormen. De grens tussen -brecht- en -brechts-vormen loopt in Vlaanderen ter hoogte van de Schelde-Dender. Het gaat om een verbluffend scherpe grens, temeer daar hier meer dan 200 verschillende namen gegroepeerd zijn. In Nederland sluiten de westelijk-Noord-Brabantse -brechts-vormen aan bij het Vlaamse genitiefgebied. Ten noorden van het Rivierengebied overweegt de -brecht-variant, zij het dat dit patroniemtype daar globaal zeldzamer is (cfr. MARYNISSEN 1997:34$35)$.

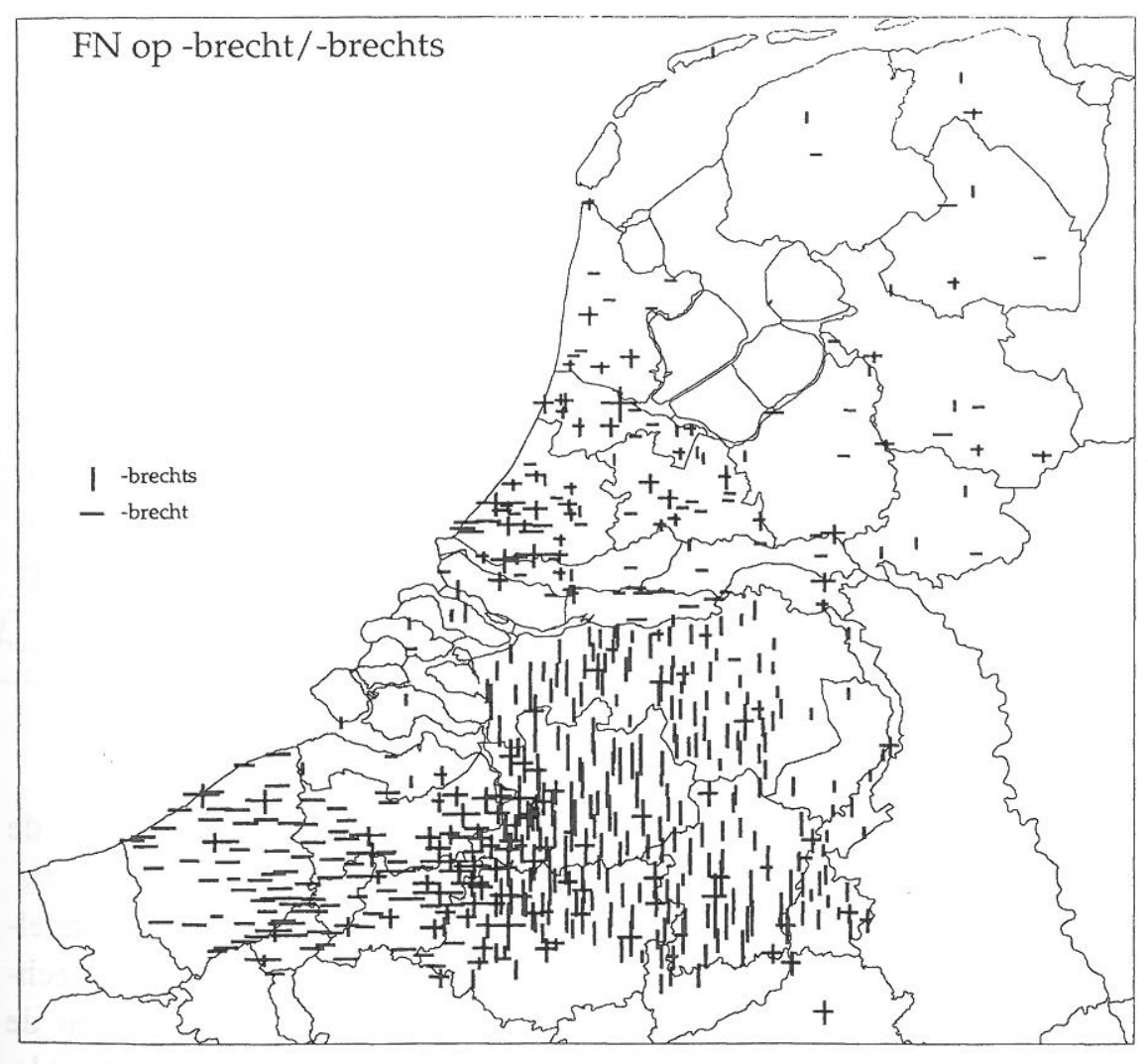

A. Marynissen 
Niet alleen om morfosyntactische contrasten weer te geven, maar ook om klankgeografische tegenstellingen, spellingverschillen en lexicale verschillen in de FN weer te geven, is dit kaarttype geschikt. Als aanvulling bij de toponymische heteroniemenkaart van Lindemans (kaart 2) heb ik de heteronymie in de benamingen voor de "hooiweide" in de familienamen gekarteerd : kaart 15 : 'beemd' / 'meers' / 'made' in FN.

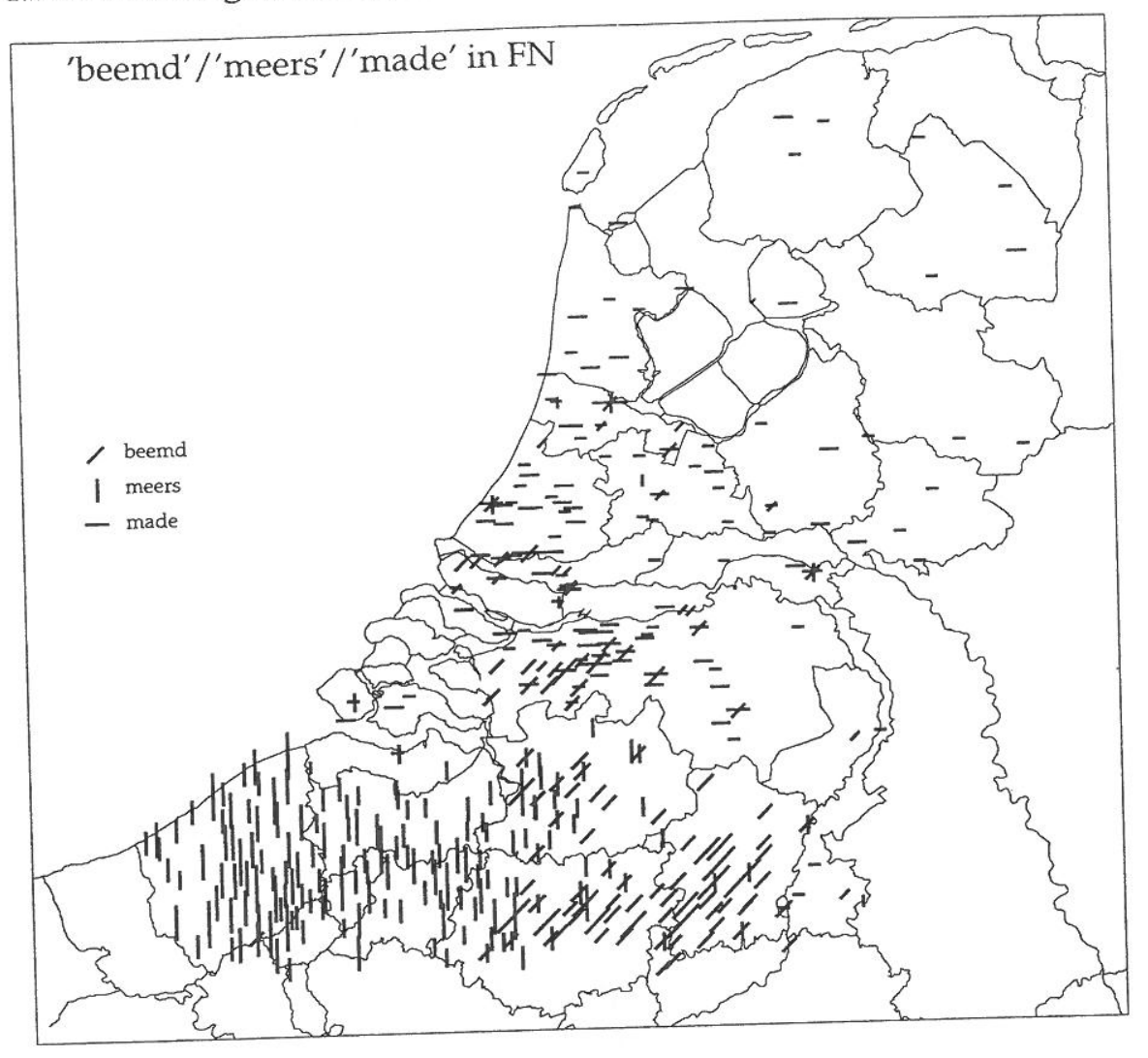

A. Marynissen

Er is een opvallende overeenstemming tussen de verspreiding van de toponiemen en van de familienamen die teruggaan op beemd en meers. Het beemd-gebied in de FN stemt overeen met Lindemans' voorstelling van de verspreiding van dat toponiem. FN met meers blijken echter oostelijker voor te komen dan op Lindemans' kaart, waarop de oostelijke grens van de meers-toponiemen samenviel met de Schelde. 
Die expansie naar het westen van Brabant en Antwerpen, waar de FN Vermeersch en Vandenbempt nu naast elkaar voorkomen, is te verklaren uit de woordgeschiedenis van meers, dat zich in de loop der eeuwen geleidelijk meer naar het oosten verspreid heeft(6). Dat er in het Vlaamse kustgebied geen familienamen met meet bewaard zijn, heeft eveneens te maken met de woordgeschiedenis van meet: dat woord was niet meer productief op het ogenblik van de vorming van FN. Meet leeft enkel voort in zeer oude toponiemen; de toponymische vindplaatsen van meet zijn ouder dan die van beemd en meers(7). In Nederland heeft de vorm made kennelijk langer tot het levende lexicon behoord en was het, als het tenminste om hetzelfde woord gaat( 8$)$, niet enkel een kustwoord; dat leiden we tenminste af uit het bestaan van FN Van der Made(n) in Nederland en uit de vrij ruime verspreiding ervan.

Hoewel in de $\mathrm{FN}$-geografie vaak terecht puntkaarten worden getekend, is voor een geografie van de lexicale motivering van FN de vlakkenmethode wel de beste keuze. Een voorbeeld is de kaart van J. Goossens uit zijn artikel "Motiefgeografie van Nederlandse familienamen" met daarop het aandeel van de patroniemen aan de twintig frequentste $\mathrm{FN}$ in de Nederlandse en Vlaamse provincies (kaart 16 : GoOSSENS 1995b: 26).

Met een ander doel voor ogen, nl. om er iets over migratiepatronen binnen de provincie uit af te leiden, had Heeroma voordien, in de inleiding van het Repertoriumdeel over Gelderland (p. 61), de verspreiding van Gelderse herkomstnamen in Gelderland al in kaart gebracht. Hij heeft dat nadien in een artikel overgedaan voor de inheemse her-

(6) Met dank aan Sven Naujokat, die de beemd-, meers- en meet-toponiemen uit het Corpus Molemans-Thiry, waarop deze vaststelling gebaseerd is, geëxcerpeerd heeft.

(7) Idem vorige noot.

(8) J. Lindemans b.v. betwijfelt of meet en made gelijkgeschakeld mogen worden: "De hypothese lijkt ons gewettigd dat de maatnamen, in het Noorden van de provincie Oost-Vlaanderen, van een anderen oorsprong zijn dan de meetnamen uit het kustgebied. Zij sluiten aan bij de made-, maai-, maat-namen die, alhoewel niet zeer talrijk, in Noord-Brabant en de Antwerpsche Kempen voorkomen" (LINDEMANS 1946:73). 
komstnamen uit het noordoosten van Noord-Brabant (kaart 17: HEEROMA 1972:29).

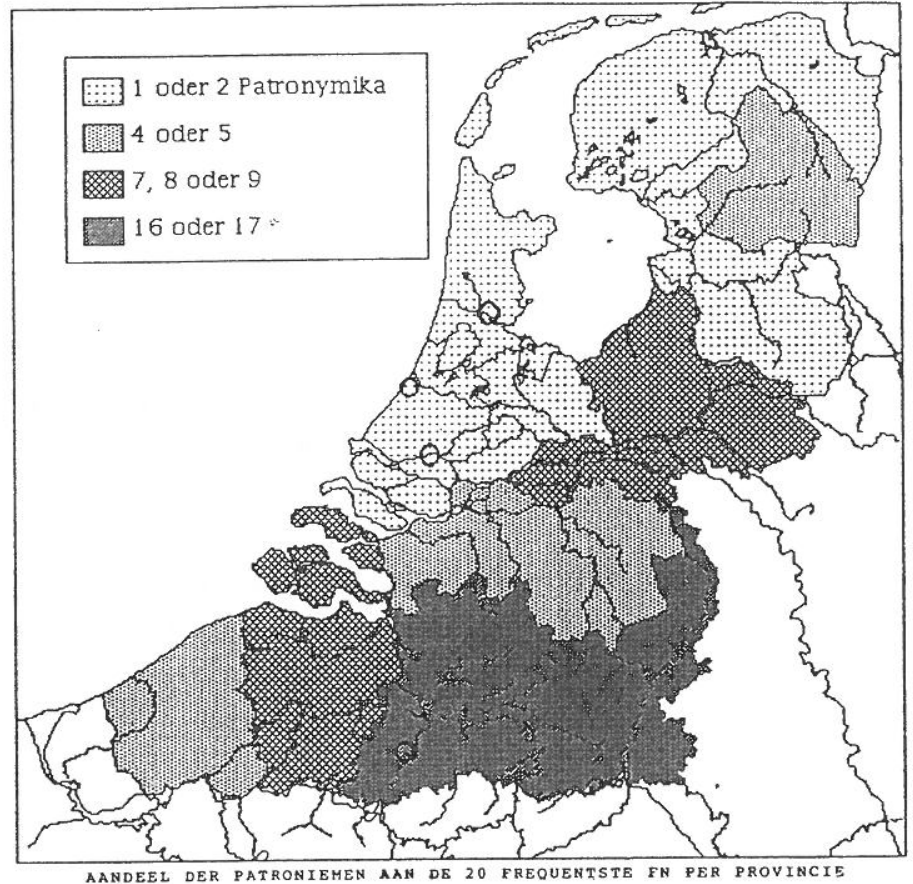

Uit: Goossens 1995b: 26

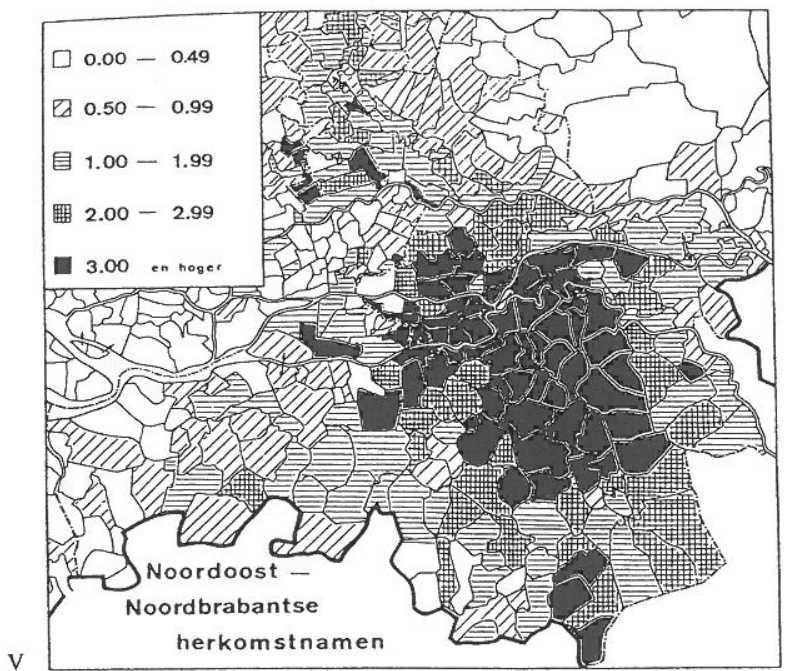

Uit: Heeroma 1972: 29 
De emigratie van Vlaanderen naar Wallonië is af te lezen uit de puntsymboolkaart van W. Beele, waarbij de percentages die hij heeft ingetekend het aantal van-namen per telefoonzone voorstellen. In de zones die aan Vlaanderen grenzen, liggen die aanzienlijk hoger dan zuidelijker in Wallonië (kaart 18 : BEELE 1996:1166).

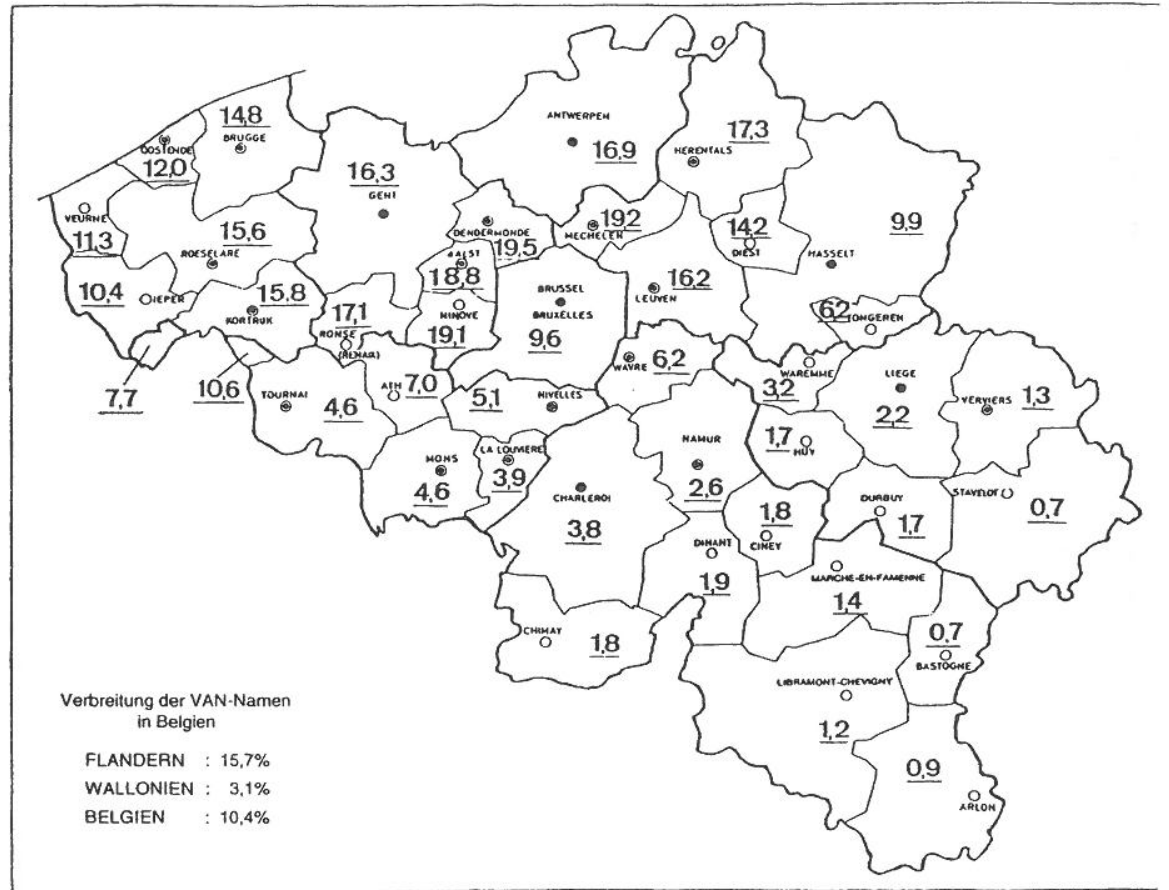

Karte 175.1: Verbreitung der biat-Natien in Belpicn

Uit: Beele 1996: 1166

Een linguïstische probleemstelling tenslotte ligt aan de basis van tal van familienaamkaarten die J. Van Loon getekend heeft. Hij heeft verschillende vlakkenkaarten gemaakt waarop hij morfologische contrasten in de vorm van isomorfen voorstelt. Een mooi voorbeeld is de kaart waarop hij tegenstellingen in de flexie van de Nederlandse herkomstnamen weergeeft : hij combineert hier de variatie in de buigingsuitgang (Verhoef, Verhoeve of Verhoeven), met de variatie in de aanloop van de namen (met Vander- of samengetrokken tot Ver-) : kaart 19: VAN LOON 1996:1163. 


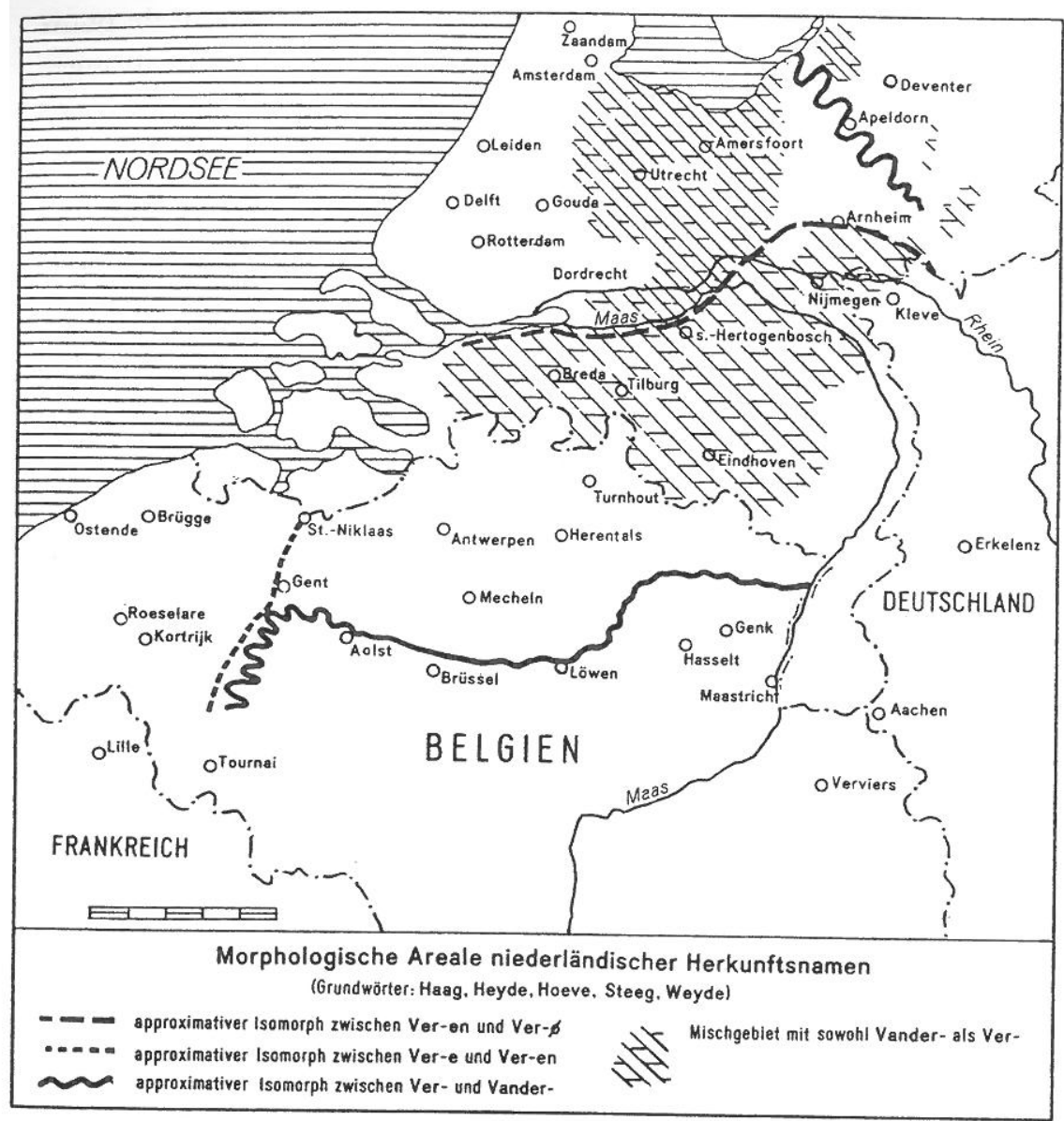

Karte 174.8: Morphologische Areale niederländischer Herkunftsnamen Uit: Van Loon 1996: 1163

\section{Conclusie}

De methodes die bij de kartering van naamkundige gegevens gebruikt worden, zijn grotendeels dezelfde als degene die in de dialectgeografie en de historische taalgeografie gebruikelijk zijn: de hoofdtypes zijn vlakkenkaarten en (complexe) puntsymboolkaarten. Om de specifiek naamkundige accenten tot hun recht te laten komen, wordt er evenwel creatief omgegaan met deze twee karteringswijzen. Door de aard van het materiaal en door de aard van de vraagstellingen, moet in de naam- 
geografie b.v. vaak naar een manier worden gezocht om de factor frequentie adequaat op de kaarten weer te geven.

\section{Bibliografie}

A. BACH, Deutsche Namenkunde, I. Die deutschen Personennamen, 12. Die deutschen Ortsnamen, 1-2. Heidelberg, 1952-1954.

W. BEELE, Van-namen als Auswanderungsmesser. In : E. EICHLER u. A. (Hrsg.) : Namenforschung. Ein internationales Handbuch zur Onomastik. 2. Teilband. Berlin/New York, 1996, 1164-1169.

D.P. BLOK e.a., Algemene Geschiedenis der Nederlanden. Deel I. Haarlem, 1981.

H. BUITENHUIS, Das niederländische Repertorium der Familiennamen. In: Beiträge zur Namenforschung N.F. 12 (1977), 35-63.

W. CIURAJ e.a., Die Flurnamen der Stadt Isselburg. Atlas und Namenregister. Westmünsterländische Flurnamen, Band 5. Im Auftrage des Landeskundlichen Instituts Westmünsterland herausgegeben von Ludger Kremer und Timothy Sodmann. Vreden/Isselburg 1990.

A. DEES, Atlas des formes et des constructions des chartes françaises du 13 e siècle. Avec le concours de P. Th. van Reenen et de J.A. de Vries. Tübingen, 1980.

A. DeEs, Atlas des formes linguistiques des textes littéraires de l'ancien français. Avec le concours de M. Dekker, O. Huber et K. van Reenen-Stein. Tübingen, 1987.

M. DeVos, Bouwlandtermen in de Vlaamse dialecten. Spreidings- en betekenisgeschiedenis. Werken van de Koninklijke Commissie voor Toponymie en Dialectologie, Vlaamse afdeling, 16. Tongeren, 1991.

K. GILDEMACHER, Waternamen in Friesland. Ljouwert, 1993.

J. GOOSSENS (1995a), Karteringsmogelijkheden in de historische taalgeografie. In : Taal \& Tongval 1995, themanummer 8, historische dialectologie, 186-203.

J. Goossens (1995b), Motiefgeografie van Nederlandse familienamen. In : Naamkunde 27 (1995), 1-31. 
J. Goossens, Familiennamengeographie. In : E. EICHLER u.A. (Hrsg.), Namenforschung. Ein internationales Handbuch zur Onomastik. 2. Teilband. Berlin/New York, 1996, 1141-1153.

K. Heeroma, Drent(h), Groninger, de Vries (en de Jong). In : Driemaandelijkse Bladen 17 (1965), 22-42.

K. HEEROMA, Familiennamengeographie im Osten der Niederlande. In : Beiträge zur Namenforschung N.F. 3 (1968), 1-18.

K. HeEROMA, De verspreiding van een groep herkomstnamen uit het noordoosten van Noord-Brabant. In : H. Buitenhuis en K. Heeroma, Noordbrabantse herkomstnamen. Amsterdam, 1972, 21-35.

P. KEMPENEERS, Hydronymie van het Dijle- en Netebekken. Diss. Leuven, 1982.

K. KUNZE, Dtv-Atlas Namenkunde. Vor- und Familiennamen im deutschen Sprachgebiet. München, 19992.

J. LINDEMANS, Toponymische verschijnselen geografisch bewerkt. Nomina geographica flandrica, Studiën V, 1, 2, 3. Brussel, 1940, 1946, 1954.

A. MARYNISSEN, The geographical distribution of toponymical elements in the Dutch-speaking part of Belgium. In: E.M. NÄRHI (Ed.), Proceedings of the XVIIth International Congress of Onomastics, Helsinki 13-18 August 1990 (Helsinki, 1990), Vol. 2, 147154.

A. MARYNISSEN, Naar aanleiding van de publikatie van de "Hessischer Flurnamenatlas". Naamkunde 24 (1992), 205-212.

A. MARYNISSEN, Waar komt mijn familienaam voor ? Automatische kartering van de geografische spreiding van (types) familienamen in het Nederlandse taalgebied. In : De Aardrijkskunde 21 (1997), nr. 3, 25-38.

A. MONJOUR, Les noms de lieux français en $-n+-i a c u>-n y$ ou : peuton distinguer des espaces dialectaux ? In: Revue de linguistique romane 57 (1993), 93-122.

G. MULLER, Ein westfälisch-lippischer Flurnamenatlas. Zum Einsatz von Sprachkarten bei der Veröffentlichung der Daten des Westfälischen Flurnamenarchivs. In: Niederdeutsches Wort 24 (1984), 61128.

H. RAMGE (Hrsg.), Hessischer Flurnamenatlas. Arbeiten der Hessischen Historischen Kommission, N.F. Band 3. Darmstadt, 1987.

W. VAN LANGENDONCK, Geografie van de voor- en toenaampatronen in de Vlaamse dialekten. In : Naamkunde 23 (1991), 9-20. 
J. VAN LOON, Familiennamengeographie und -morphologie. In : E. EICHLER u.A. (Hrsg.), Namenforschung. Ein internationales Handbuch zur Onomastik. 2. Teilband. Berlin/New York, 1996, 1153-1163.

Winksele

Ann MARYNISSEN 